Editorials

\title{
Commentary-How do we Improve Training for Receptor Research?
}

\author{
Marilee Ann Benore \\ Department of Natural Sciences, University of Michigan-Dearborn, 4901 Evergreen Road, Dearborn, MI 48128, USA
}

Article history

Received: 09-09-2015

Revised: 28-09-2015

Accepted: 10-10-2015

Email: Marilee@umich.edu

\begin{abstract}
Training of students and scientists to carry out receptor research has lagged behind progress in other areas of biochemistry and biotechnology. In this commentary suggestions for improving curriculum, strategies for incorporating topics into lecture and laboratories and references are suggested. In addition, this call for action suggests that those in industry and research laboratories assume a greater role in training.
\end{abstract}

Keywords: Training, Receptor, Programs, Internship, Education
This issue of the American Journal of Biochemistry and Biotechnology features articles about receptor-ligand interactions that are critical to the wellbeing of all living organisms. The importance of the field of receptor research is supported by the large number of articles published in journals, the numerous specialty journals, the international conferences and the percentage of legal drugs on the market that target receptors. There are several journals dedicated to receptor or ligand study, including those in biochemistry, pharmacy and synthesis. Both large and small conferences have sessions devoted in part or completely to the topic. There are over 1 million hits in response to the query "receptor" and over 4 million to the query "drug" in PubMed (as of July, 2015). (http://www.ncbi.nlm.nih.gov/pubmed).

Most drugs approved for use in humans target receptors. In their Nature Reviews paper entitled "Drugs, their targets and the nature and number of drug targets", Imming and colleagues examined drug targets, characterizing the drugs in consideration of the human genome (Imming et al., 2006). They developed a detailed classification system: Defining a target as a molecular structure that undergoes an interaction with a chemical that is connected to a clinical effect. Eight physiological target categories were described: Enzymes; receptors; ion channels; transport proteins; DNA/RNA/ribosome; monoclonal antibodies; substrates, metabolites and proteins; and various physicochemical mechanisms.

This topic was further explored by Rask-Andersen and others in the 2011 Nature Review article "Trends in the exploitation of novel drug targets" (Rask-Andersen et al., 2011). They analyzed the US Food and Drug Administration (FDA) approved drugs as well as the DrugBank database to determine trends in drug development and approval (http://www.drugbank.ca/). Their curated list of 989 drugs with therapeutic effects on 435 targets resulted in the following data about the targets: Receptors account for $44 \%$, transporters $15 \%$, enzymes $29 \%$ and the category of "other" $12 \%$. Thus, the inclusion of receptors and transporters accounts for more than half of the drugs approved by the FDA. Since even drugs that stimulate enzyme cascades often first interact with receptors, ion channels or membrane carriers, the significance of receptors in physiology is clear.

Yet few undergraduate students of biology, chemistry or biochemistry are trained to study receptors or kinetic methods unless they have research experience. They study similar and related topics: Students in chemistry study the stoichiometry of reactions and equilibria, while biology students study the product formation of enzymes. But many students are unable to predict how many receptors will be saturated if the ligand concentration is the same as the binding affinity of a given receptor. The emphasis on catalysis is understandable because metabolism, which is dependent on enzymes, has been a dominant theme in physiology and biochemistry courses. Student in a biochemistry course can relay the details of MichaelisMenten kinetics, yet few recognize the name Scatchard (Michaelis and Menten, 1913; Scatchard, 1949). Of course, students in neuroscience or prepharmacy programs are more likely to learn about receptors, agonists and antagonists. The emerging significance of homeostasis will likely increase curricular content of receptor mechanisms. In addition, the focus on skills should help develop students with the mathematical and laboratory expertise to devise experiments studying receptors (White et al., 2013). (See the updated guidelines for Biochemistry education at www.asbmb.org). 
While the information about receptors in courses, texts and lab experiences provide examples there is often little theory and limited application. Chapters in texts focus on the outcomes of the processes, such as transport of water molecules across a membrane, receptor-mediated endocytosis of the LDL receptor and second messenger actions. Unlike enzymes, there is minimal detail on the experimentation, the classic research or kinetic aspects. There are relatively few new books dedicated to the topic, with the exceptions being the well-known pharmacology texts by Goodman and Gilman and by Foreman and Johansen. The surge in neurology research has led to more medically related texts, such as by Allen. Many of us still use the old texts available, such as Yamamura et al. (1976) or my personal favorite, the long out-of-print Quantitative Problems in the Biochemical Sciences by Montgomery and Swenson (Table 1).

So how do we prepare the next generation of scientists who will be excited about and qualified to carry out this research? We begin by including more examples in the class and laboratory experiences of students. If a student can learn rudimentary catalysis, it is a relatively easy matter to study simple receptors due to the similarities: Saturation, binding affinity and assay development (Benore-Parsons and Sufka, 2001).

Lecture courses should include more examples and problems to test understanding. Excellent articles are available on incorporating topics, such as those in education journals (Sears et al., 2007). Case-based and problem-based learning provide relevant examples. The National Center for Case Study Teaching in Science maintains a web site for examples (see http://sciencecases.lib.buffalo.edu/cs/collection/).

Problems that incorporate descriptions of the methods or specific drug targets are especially helpful.

The use of a "theme" or "threaded" topic during the semester is also useful in providing a continuous example and full picture of receptor mechanisms. For example, this method has been successfully used to teach entire courses using the AIDs virus or other topics as the thread (Grover, 2008; Casselton et al., 2008; White, 2002). In my non-major biochemistry class I incorporate a threaded topic, using insulin as the example woven through the topics all semester. Over the term students learn about insulin protein structure, the history of its discovery, it's function, gene and receptor. The development of ELISA techniques and binding of recombinant versions to the receptor are investigated. Students are surprised that insulin is both a ligand and a protein and this leads to discussions about site-directed mutagenesis, recombinant insulin versions and binding affinities of the insulin analogues to the receptor. Signaling systems and post-receptor activation is another concept to explore. An additional useful example is to detail the processes of drug development and Food and Drug Administration approval for medications used in humans. Currently, there is a tremendous increase in the abundance of protein sequence information and in many cases clear documentation of sequence variations that exist for receptors in the human genome. Thus, an important topic would be mutations of the insulin receptor that can lead to diabetes. The threaded series of related topics provides an overview of the many approaches used in receptor research.

Laboratory experience is just as valuable, indeed essential. In my advanced biochemistry laboratory course the focus was on ligands, receptors and transporters. Students learned to carry out ELISA experiments using a BioRad kit. We followed the Bio Rad quantitative protocol with a second set of student designed experiments. Their goal was to investigate the impact of physiological agents on the accuracy of the ELISA and identify drugs that might interfere with the activity and accuracy of the assay. Students write up the conclusions as if they were testing the system for a law case to render results inaccurate. Following this experiment, students studied binding and competition using the avidin-biotin system, with HABA as a competing agent (Ninfa et al., 2009). Finally, they purified and characterized the transport protein Riboflavin Binding Protein, easily monitored by the bright yellow of the riboflavin ligand, using a modified version of the literature protocol (Miller and White, 1986). Problems and quizzes accompanied the experiments to ensure understanding. By the end of the term students were well versed in how to purify and characterize a protein, determine binding affinity using Scatchard plots and carry out competition curves.

Table 1. Textbooks and resources for learning about receptors and ligands

- Textbook of Receptor Pharmacology, Third Edition (2010) John C. Foreman (Editor), Torben Johansen (Editor), CRC Press, BocaRaton, Fl

- $\quad$ Signaling by Receptor Tyrosine Kinases (Subject Collection from Cold Spring Harbor Perspectives in Biology) (2014) Joseph Schlessinger and Mark A. Lemmon (Editors) Cold Spring harbor Press, Cold Spring harbor, MA

- $\quad$ Receptor Based Solutions; Functional Neurology Every Doctor Should Know (2014) Michael D. Allen, Healthbuilders Publishing

- Goodman and Gilman's The Pharmacological Basis of Therapeutics, Twelfth Edition (2011) Laurence L. Brunton, Bruce A. Chabner, Björn C. Knollmann, McGraw-Hill Companies, China

- $\quad$ Neurotransmitter receptor binding. (1978) H.I. Yamamura, S. J. Enna and M. J. Kuhar, Editors, Raven Press, New York

- Quantitative problems in the biochemical sciences, 2nd edition (1976) R. Montgomery and C. A. Swenson, W. H. Freeman, San Francisco, CA 
Finally, what can researchers do to improve the training of future scientists? Those scientists immersed in receptor research should participate in education. Internships, research experiences and opportunities in academics or in industry should be made available to students interested in pursuing these careers (Callier et al., 2014). Researchers in industry should make the effort to offer to give seminars at local Universities, or host site visits.

With these efforts, the next generation of researchers will be prepared to innovate and collaborate in drug, ligand and receptor discovery and characterization.

\section{Acknowledgement}

The author thanks Lawrence Wennogle for critical reading and suggestions. The author notes that $\mathrm{Dr}$ Wennogle was her postdoctoral advisor and is a coauthor on publications (not cited). The author thanks George Garcia for suggestions.

\section{Funding Information}

The author discloses that she is the one of the team of authors of the laboratory manual referenced in the article. The author notes that she is a member of the core team working with the ASBMB, but has no financial conflict. The author has no other financial conflicts. There is no funding support to acknowledge.

\section{Author Contributions}

The author wrote the article with input as indicated in the acknowledgements.

\section{Ethics}

This article is original and contains unpublished material. The corresponding author confirms that all of the other authors have read and approved the manuscript and no ethical issues involved.

\section{References}

Benore-Parsons, M. and K.J. Sufka, 2001. Teaching receptor theory to biochemistry undergraduates. Biochem. Molecular Biol. Educ., 31: 85-92. DOI: 10.1002/bmb.2003.494031020172

Callier, V., R.H. Singiser and N.L. Vanderford, 2014. Connecting undergraduate science education with the needs of today's graduates. F1000 Res., 3: 279-279. PMID: 25653842

Casselton, J., J. Kraynik, H. Underhaul and N. Grover, 2008. Creating outreach activities to match students' interest: HIV/AIDS education in Tanzania. ASBMB Today, 1: 22-24.
Grover, N., 2008. Linking teaching, research and service at an undergraduate institution. ASBMB Today, 6: 20-29.

Imming, P., C. Sinning and A. Meyer, 2006. Drugs, their targets and the nature and number of drug targets. Nature Rev. Drug Discovery, 5: 821-834. DOI: $10.1038 / \mathrm{nrd} 2132$

Michaelis, L. and M.L. Menten, 1913. Die Kinetik der Invertinwirkung. Biochem. Z, 49: 333-369.

Miller, M.S. and H.B. White, 1986. Isolation of avian riboflavin-binding protein. Methods Enzymol., 122: 227-2234. PMID: 3702691

Ninfa, A.J., D.P. Ballou and M. Benore, 2009. Fundamental Laboratory Approaches for Biochemistry and Biotechnology. 2nd Edn., John Wiley and Sons, Hoboken, NJ, ISBN-10: 0470087668, pp: 480.

Rask-Andersen, M., M.S. Almén and H.B. Schiöth, 2011. Trends in the exploitation of novel drug targets. Nature Rev. Drug Discovery, 10: 579-590. DOI: $10.1038 / \mathrm{nrd} 3478$

Scatchard, G., 1949. The attractions of proteins for small molecules and ions. Ann. New York Acad. Sci., 61: 660-672. DOI: 10.1111/j.1749-6632.1949.tb27297.x

Sears, D.W., S.E. Thompson and S.R. Saxon, 2007. Reversible ligand binding reactions: Why do biochemistry students have trouble connecting the dots? Biochem. Mol. Biol. Educ., 35: 105-118. PMID: 21591070

White, H.B., 2002. Classic articles as problem-based learning problems. Biochem. Mol. Biol. Educ., 30: 313-314. DOI: $10.1002 / \mathrm{bmb} .2002 .494030050112$

White, H.B., M.A. Benore, T.F. Sumter and B.D. Caldwell, 2013. What skills should students of undergraduate biochemistry and molecular biology programs have upon graduation? Biochem. Mol. Biol. Educ., 41: 297-301. DOI: 10.1002/bmb.20729 